Jurnal ABDIMAS INDEPENDEN

Vol. 1, No. 2, November 2020

\title{
PEMBERDAYAAN WANITA NELAYAN MELALUI PEMANFAATAN SAMPAH NON-ORGANIK SEBAGAI UPAYA MENAMBAH PENDAPATAN MASYARAKAT DI DESA KURANJI DALANG KECAMATAN LABUAPI KABUPATEN LOMBOK BARAT
}

\author{
Bq Ismiwati ${ }^{1)}$, Taufik Chaidir ${ }^{2)}$, Ida Ayu Putri $\mathrm{S}^{3)}$, Abdul Manan $^{4)}$ \\ Jurusan Ilmu Ekonomi dan Studi Pembangunan (IESP) - Universitas Mataram \\ ismiwati2010@gmail.com
}

\begin{abstract}
ABSTRAK
Peran wanita nelayan sangat dibutuhkan dalam mengelola hasil tangkapan nelayan sampai menghasilkan uang. Namun sebagian besar memiliki kemampuan dan keterampilan yang terbatas. Umumnya para wanita nelayan menganggur dan tidak tahu berbuat apa untuk membantu perekonomian keluarga. Disisi lain lingkungan pantai tempat tinggal mereka masih kotor oleh sampah, termasuk sampah non-organik. Sampah non-organik belum dimanfaatkan secara ekonomis oleh kaum perempuan nelayan untuk menambah pendapatan keluarga. Tujuan pengabdian ini adalah untuk memberdayakan kaum wanita nelayan yang ada di desa Kuranji dalang agar dapat memanfaatkan sampah non organik disekitar mereka sebagai produk yang bernilai tinggi yang nantinya dapat membantu mereka untuk memperoleh tambahan pendapatan sehingga dapat membantu mengembangkan ekonomi keluarga. Sekaligus dapat membantu untuk menjaga lingkungan sekitar daerah pantai agar terhindar dari pencemaran sampah non-organik sehingga akan tercipta lingkungan pantai yang bersih. Metode pemecahan masalah meliputi: melatih pengolahan sampah nonorganik menjadi produk bernilai ekonomi, seperti: Inke, bunga, tas; melatih pengelolaan usaha sederhana; penyuluhan tenptang kebersihan lingkungan. Pemberdayaan yang dilakukan dipandang berhasil, dilihat dari adanya perubahan pada beberapa wanita nelayan yang sudah mulai membuat kerajinan dari sampah non-organik berupa inke, meski pada awalnya mereka hanya menghasilkan untuk dipakai sendiri. Dan terlihat lingkungan pantai sudah mulai bersih dari sampah non-organik. Dapat disimpulkan bahwa kegiatan pemberdayaan pada wanita nelayan berhasil dilihat dari antusiasme para peserta pada saat pelatihan, Keseriusan para peserta untuk memperdalam penguasan tentang sampah plastik. Terlihat bahwa outcome dari pelatihan ini mengarah pada proses perubahan sampah plastik menjadi produk bernilai ekonomis mengarah pada peningkatan pendapatan.
\end{abstract}

Kata kunci: Pemberdayaan, Sampah non-organik, pendapatan. 


\section{ABSTRACT}

The roles of fisherman's wifes are really needed in post harvest fisheries processing to make money. But, most of them lack in ability and skill. They commonly do not work and do not know what to do in order to help family economy. In other side, coastal environment where they lived is full of waste including non-organic waste. Non- organic waste not yet utilized economically by the fisherman's wifes to increase family income. The aim of this community service is to empowers the fisherman's wifes in Kuranji Dalang Village to utilized the non-organic waste around them as a valuable product so that it can helps them to increase their income and helps to develop family economy. Other than that, it can also helps protect the environment around the coastal from nonorganic waste pollution and keep it clean. The methods used to solved the problem include: Non-organic waste recycling training to make a economically valuable product such as: Inke (traditional plate), flower, bag; small business management training; counseling about the cleanliness of environment. The empowerments carried out seen as sucessful from the change that seen in several fisherman's wifes started making craft from non-organic waste in the form of inke, although at first, they just produce a product for their private use and coastal environment started to look free from non-organic waste. It can be concluded that the empowerments activity in fisherman's wifes is sucessful seen from the antusiasm of the participants when trained, seriousness of them to know deeper about plastic waste. It can be seen that the outcome of this training leads to the processing of plastic waste to economically valuable product that can leads to increasing income.

Keywords: Empowerment, Non-Organic waste, Income.

\section{PENDAHULUAN}

Pendidikan lingkungan hidup (environmental education) adalah sustu proses untuk membanngun seluruh umat manusia di dunia sadar dan peduli terhadap lingkungan dan segala masalah yang berkaitan dengannya. Permasalahan tersebut tidak terlepas dari masyarakat yang memiliki pengetahuan, keterampilan, sikap dan tingkah laku, motivasi serta komitmen untuk bekerjasama untuk dapat memecahkan berbagai masalah lingkungan saat ini dan mencegah timbulnya masalah baru. Pasal 5 Undang Undang Pengelolaan Lingkungan Hidup No.23 Th1997, menyatakan bahwa masyarakat berhak atas lingkungan hidup yang baik dan sehat. Untuk mendapatkan hak tersebut, pada 


\section{Jurnal ABDIMAS INDEPENDEN}

Vol. 1, No. 2, November 2020

pasal 6 dinyatakan bahwa masyarakat dan pengusaha berkewajiban untuk berpartisipasi dalam memelihara kelestarian fungsi lingkungan, mencegah dan menanggulangi pencemaran dan kerusakan lingkungan. Terkait dengan ketentuan tersebut, dalam UU No.18 Tahun 2008 secara eksplisit juga dinyatakan bahwa setiap orang mempunyai hak dan kewajiban dalam pengelolaan. Dalam Hal pengelolaan sampah pasal 12 dinyatakan, setiap orang wajip mengurangi dan menangani sampah dengan cara berwawasan lingkungan. Tidak terkecuali baik dari perorangan, rumah tangga, dusun, desa, sampai ke tingkat pemerintahan yang lebih atas, dianjurkan untuk dapat menangani sampah, baik sampah organik maupun sampah non-organik.

Desa Kuranji Dalang merupakan salah satu desa pemekaran dari desa Kuranji yang ada di Kecamatan Labuapi. Letak Desa ini berhadapan langsung dengan pantai, dimana dua dari lima dusun yang ada terletak dipinggir pantai. Penduduk Desa Kuranji Dalang terpusat di dua dusun ini, yakni dusun Kuranji Dalang dan Dusun Kuranji Bangsal.Berdasarkan kenyataan ini, banyak penduduk dari desa Kuranji Dalang bermata pencaharian sebagai nelayan. Dari Potensi Desa Kuranji Dalang diperoleh data bahwa dari 1341 orang penduduk (498 KK) yang berdomisili di sekitar pantai, sebanyak 250 orang diantaranya bermata pencaharian sebagai nelayan.

Seperti daerah nelayan pada umumnya, masyarakat pesisir ini banyak yang hidup dalam keterbatasan ekonomi. Umumnya mereka hanya mengharapkan hasil tangkapan sebagai sumber penghasilan yang utama. Sementara hasil dari nelayan sangat terbatas dan sangat tergantung pada kondisi alam (tergantung pada musim). Pada musim-musim tertentu para nelayan tidak dapat melaut sementara mereka butuh makan untuk melanjutkan hidup.

Disini peran para istri nelayan adalah mengolah hasil tangkapan para suami sampai menghasilkan uang untuk memenuhi kebutuhan hidup mereka sekeluarga. Peran wanita nelayan untuk membantu dan mendukung suami sangat diperlukan. Namun jika dilihat dari para wanita nelayan yang ada, 
sebagian besar memiliki kemampuan dan keterampilan yang terbatas. Kemampuan mereka hanya terbatas pada pengolahan hasil tangkapan menjadi ikan pindang atau ikan kering, itupun jika ada yang tidak habis terjual segar. Hanya sebagian saja dari mereka yang memiliki ketrampilan sebagai pengolah hasil tangkapan menjadi produk olahan ikan seperti abon ikan, kerupuk ikan, ikan asin dan beberapa produk olahan lainnya yang dapat memberikan nilai tambah pada hasil tangkapan sehingga dapat menambah penghasilan keluarga nelayan dan. tentunya sangat membantu untuk meningkatkan perekonomian keluarga. Kemampuan wanita nelayan dalam mengelola usaha produk olahan ikan juga masih lemah.Secara umum kondisi ekonomi masyarakat nelayan di daerah ini masih rendah. Masih banyak wanita nelayan yang menganggur dan tidak tahu berbuat apa untuk membantu perekonomian keluarga. Wanita nelayan di daerah ini umumnya memiliki kemampuan yang terbatas dengan pendidikan yang juga sangat terbatas. Rata-rata pendidikan wanita nelayan hanya tamat SD, banyak juga yang tidak tamat SD dan bahkan tidak pernah mengenyam bangku sekolah.

Di sisi lain, meski Desa Kuranji Dalang (khususnya dusun Kuranji Bangsal dan Dusun Kuranji Dalang) termasuk sebagai daerah wisata yang sudah mulai dikunjungi oleh para wisatawan lokal, namun kondisi pantainya masih kotor dan banyak sampah berserakan disekitar pantai. Kesadaran para pengunjung dipantai maupun masyarakat sekitar masih rendah tentang kebersihan lingkungan, sehingga masalah sampah didaerah ini masih kurang teratasi. Diantara sampah yang berserakan, banyak terdapat sampah non-organik (plastik), seperti botol plastik, gelas plastik bekas minuman kemasan, kulit permen maupun plastikplastik bekas kemasan makanan ringan ataupun plastik bekas kemasan kopi instan dan lain sebagainya. Hal ini tentunya akan merusak lingkungan, karena sampah plastik merupakan materi yang tidak cepat diurai dan hancur menyatu dengan tanah. Kondisi ini tentunya tidak baik kalau dibiarkan berkelanjutan tanpa ada solusi yang tepat untuk mengatasinya. 


\section{Jurnal ABDIMAS INDEPENDEN}

Vol. 1, No. 2, November 2020

Masalah sampah non-organik ini dapat diatasi dengan memanfaatkannya sebagai bahan dasar untuk diolah menjadi berbagai produk yang bernilai ekonomis dan dapat menghasilkan uang bila ditekuni secara serius. Produk hasil pemanfaatan sampah non-organik ini dapat berupa tas, topi, kopiah, bunga, keranjang pakaian, tempat minuman (air mineral) kemasan, piring/ingke, dan berbagai produk lainnya.

Untuk meningkatkan peran perempuan dalam keluarga, dapat dilakukan melalui peningkatan usaha-usaha ekonomi kreatif yang salah satunya adalah pengolahan sampah non-organik yang semula tidak bernilai, mengotori lingkungan, menimbulkan bau, mengganggu kesehatan dan lainnya menjadi barang yang berguna dan bernilai ekonomis. Prinsipnya adalah meminimalisasi timbulnya sampah, memanfaatkan dan mendaur ulang sampah (prinsip 3Rreduce, reuce, recycle). Dengan prinsip ini tentunya akan mendatangkan manfaat ekonomi dan menjadikan lingkungan bersih, yang akan dapat dirasakan manfaatnya secara langsung.

Berdasarkan analisis situasi dan permasalahan yang dihadapi wanita nelayan di Desa Kuranji Dalang seperti yang telah dipaparkan diatas dan pemecahan masalah sampah non-organik seperti yang telah dikemukakan, maka kami merasa perlu untuk memberdayakan kaum wanita nelayan yang ada di desa Kuranji dalang untuk memanfaatkan sampah non organik yang ada disekitar mereka sebagai produk yang bernilai tinggi yang nantinya dapat membantu mereka untuk memperoleh tambahan pendapatan sehingga dapat membantu mengembangkan ekonomi keluarga masyarakat yang ada di Desa Kuranji dalang.. Disamping itu juga sekaligus dapat membantu untuk menjaga lingkungan sekitar daerah pantai agar terhindar dari pencemaran sampah non-organik sehingga akan tercipta lingkungan pantai yang bersih, menarik bagi para wisatawan untuk berkunjung ke daerah pantai Kuranji Dalang, kecamatan Labuapi, Kabupaten Lombok Barat. 


\section{METODE KEGIATAN}

Kegiatan pemberdayaan wanita nelayan melalui pemanfaatan sampah non-organik untuk menambah pendapatan, dilakukan dengan dua metode, yakni; (a) metode ceramah, diskusi, dan tanya-jawab untuk materi Manajemen Bisnis, dan (b) metode pelatihan ( praktik) untuk pemanfaatan sampah plastik menjadi produk kreatif bernilai ekonomis.Sementara pendampingan di lakukan selama satu bulan untuk melihat hasil dari pelatihan yang diberikan.

Pelatihan dibagi dalam dua tahap yaitu: (1). Materi tentang kebersihan lingkungan dan materi menejemen bisnis yang meliputi: Pola menejemen dana bergulir, perencanaan usaha, dan perencanaan pemasaran. (2). Pelatihan keterampilan ekonomi kreatif, yakni pelatihan mengolah sampah plastik menjadi produk bernilai ekonomi. Beberapa pelatihan dasar produk yang dilatih seperti; inke ( piring ), tas, peci, lampu hias, alas sholat dan lain-lain.

Sementara pendampingandi lakukan selama satu bulan ,namun secara non formal jika kelompok ibu-ibu nelayan memerlukan pendampingan, didampingi sampai dua bulan setelah pelaksanaan pelatihan. Pendampingan ini ditekankan pada upaya penguasaan ekononomi kreatif, dan networking.

Kegiatan pelatihan dilaksanakan di gedung Tempat Pendaratan Ikan (TPI) yang sekaligus difungsikan sebagai tempat posyandu di dusun Kuranji Bangsal, Desa Kuranji Kecamatan Labuapi pada tanggal 10 Agustus 2019.Jumlah peserta yang hadir sebanyak 26 orang dari 25 orang yang direncanakan. Ke dua puluh enam orang peserta ini masuk dalam Kelompok Wanita Tani Nelayan serta kelompok Bank Sampah yang beranggotakan wanita nelayan yang ada di dusun Kuranji Bangsal dan Dusun Kuranji Dalang.

\section{HASIL DAN PEMBAHASAN}

Untuk mengatasi berbagai permasalahan yang dihadapi oleh keluarga/wanita nelayan di Desa Kuranji Dalang Kecamatan Labuapi Kabupaten 


\section{Jurnal ABDIMAS INDEPENDEN}

Vol. 1, No. 2, November 2020

Lombok Barat ada beberapa prosedur persiapan pemecahan masalah yang dilakukan, yakni; (a) Berkomunikasi dengan bapak Kepala Desa dan Sekertaris Desa Kuranji Dalang tentang rencana kegiatan pengabdian di wilayah desa Kuranji Dalang, terutama yang terkait dengan peserta pelatihan (wanita nelayan), lokasi/tempat, dan waktu pelaksanaan kegiatan, (b)Berkoordinasi dengan Tim pengabdian selaku tutor menejemen bisnis dan tenaga tehnisi pelatihan pemanfaatan sampah non-organik menjadi berbagai produk yang bernilai ekonomis, (c) Menyepakati waktu pelaksanaan kegiatan bersama peserta pelatihan (melalui ketua kelompok wanita nelayan) agar waktu pelaksanaan kegiatan tidak berbenturan dengan kegiatan para peserta sebagai ibu rumah tangga, (d) Menyiapkan materi pelatihan yang meliputi: (1). Bahan baku sampah non-organik sebagai bahan untuk melakukan pelatihan ketrampilan ekonomi kreatif, (2). Materi manajemen bisnis yang meliputi, Pola menejemen dana bergulir, perencanaan usaha, dan perencanaan pemasaran, (3). Menyiapkan materi penyuluhan tentang kebersihan lingkungan, dan (e) Menyiapkan ATK berupa kertas, ballpoin dan alat komunikasi wireless.

Berdasarkan atas pelaksanaan kegiatan pengabdian ini, dapat diidentifikasi hal- hal sebagai berikut : (a) Umumnya para wanita nelayan sebagai peserta belum tahu cara pemanfaatan limbah plastik menjadi produk bernilai ekonomi. (b) Para wanita nelayan sebagai peserta belum memanfaatkan limbah plastik sebagai salah satu sumber pendapatan keluarga. (c) Para wanita nelayan sebagai peserta setuju untuk menerapkan pengetahuan yang didapat dari pelatihan, untuk selanjutnya dijadikan sebagai usaha menambah pendapatan, (d) Peserta sepakat, setelah mampu secara tehnis dalam memanfaatkan sampah plastik menjadi produk bernilai ekonomi, untuk mencoba mengembangkannya ke arah bisnis dengan mengaplikasikan ilmu pengetahuan manajemen bisnis yang telah didapat.

Disisi lain, terdapat faktor penghambat seperti; (a) Tingkat pendidikan peserta sebagian besar relatif rendah, sehingga terdapat peserta yang lamban 
dalam menangkap materi yang disampaikan, (b) Waktu yang tersedia relatif singkat sehingga pelatihan terasa kurang baik bagi pelatih maupun peserta, hal ini disebabkan karena peserta umumnya ibu-ibu rumah tangga yang harus segera menyiapkan keperluan keluarga.Namun demikian, terdapat faktor pendukung seperti:Adanya dukungan dari pihak pemerintah desa khususnya dari bapak Kepala Desa dan staf Desa Kuranji Dalang, motivasi yang tinggi dari Ketua dan angota Kelompok Tani Nelayan khususnya kelompok pengolah ikan Desa Kuranji Dalang selaku peserta pelatihan, dan ini sesuai dengan kebutuhannya dalam rangka pengembangan desa Kuranji Dalang sebagai Desa wisata, tersedianya TPI di Dusun Kuranji bangsal desa kuranji Dalang sebagai tempat dilaksanakannya kegiatan pengabdian, adanya dukungan dana DIPA BLU Universitas Mataram tahun 2019. dan kekompakan Tim pengabdian dalam mempersiapkan kegiatan pengabdian dari awal samapi selesai.

Pelatihan ini dapat dipandang berhasil, karena dari hasil pelaksanaan menunjukkan : (1). Tingkat kehadiran peserta yang tinggi, yakni 26 orang ( 104\% ) dari 25 orang yang direncanakan, dan mengikuti pelatihan dari awal sampai selesai. (2). Keaktipan peserta saat pelatihan cukup tinggi terlihat dari kegiatan diskusi, dan tanya-jawab.(3). Terdapat peserta yang mampu membuat produk diakhir pelatihan, walaupun hanya sebagian kecil dari peserta.(4). Adanya dukungan dari Pemerintah Desa saat pelatihan dengan menyiapkan ruangan /tempat pelatihan, (5) Keseriusan para peserta untuk memperdalam penguasan tentang sampah plastik, kemudian menularkannya kepada kaum perempuan yang lain yang ada di Desa Kuranji Dalang.(6). Adanya dukungan dari kepala Desa untuk membantu promosi sekaligus pemasaran hasil dengan rencana untuk membuat festival pepes ikan yang akan dilaksanakan di pantai Kuranji Dalang, sehingga diharapkan para pengunjung akan tertarik membeli produk dari pemanfaatan sampah non-organik, (7) Terlihat bahwa outcome dari pelatihan ini mengarah pada proses perubahan sampah plastik menjadi produk bernilai ekonomis yang berarti mengarah pada peningkatan pendapatan. Pemberdayaan 


\section{Jurnal ABDIMAS INDEPENDEN}

Vol. 1, No. 2, November 2020

yang dilakukan dipandang berhasil juga dilihat dari adanya perubahan pada beberapa wanita nelayan yang sudah mulai membuat kerajinan dari sampah non-organik berupa inke, ataupun tas meski pada awalnya mereka hanya menghasilkan untuk dipakai sendiri. Sehingga terlihat lingkungan pantai sudah mulai bersih dari sampah non-organik.
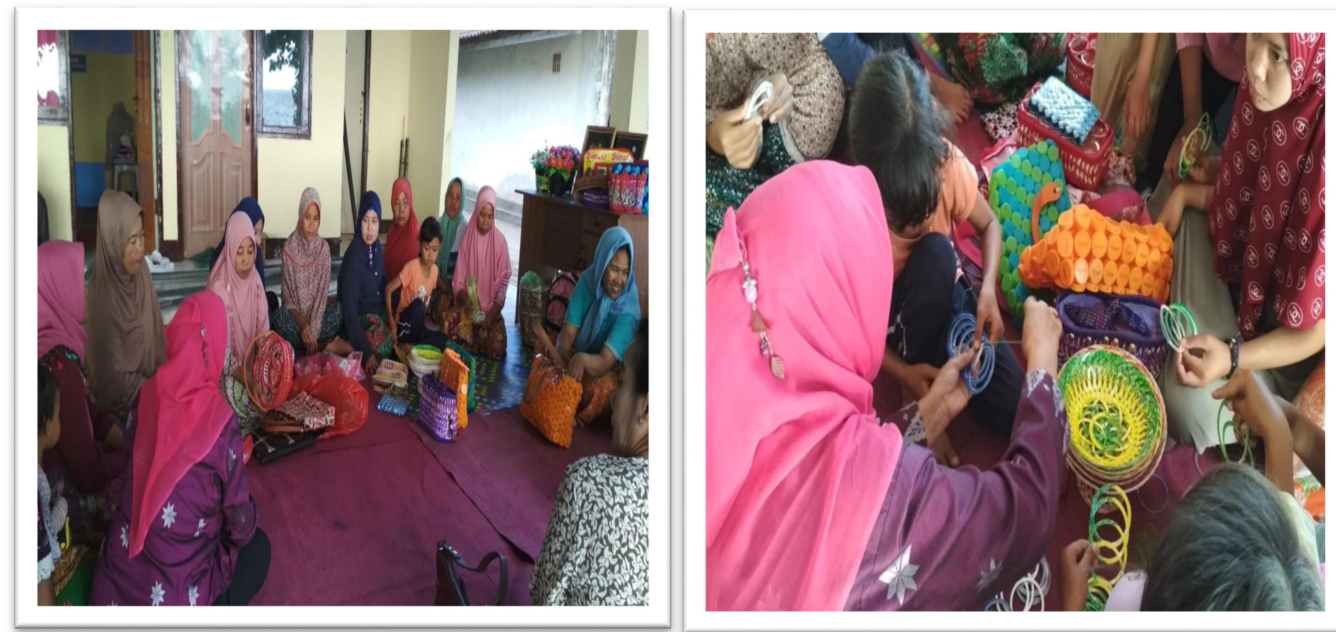

Gambar 1: Pelatihan Pembuatan Kerajinan

\section{KESIMPULAN DAN SARAN}

Berdasarkan pemberdayaan yang telah dilakukan dapat disimpulkan bahwa kegiatan pengabdian ini telah berjalan dengan lancar dan berhasil memberdayakan para wanita nelayan dengan bertambahnya pengetahuan dan ketrampilan dalam pengolahan sampah non-organik menjadi barang yang memiliki nilai ekonomi meskipun pada tahap awalnya mereka baru memproduksi untuk dipakai sendiri. I Berdasarkan hasil pengabdian, ada beberapa saran yang perlu diperhatikan, yakni :

1. Menindak lanjuti pengembangan produk dengan bahan baku plastik seperti; inke ( piring ), pot bunga, hiasan dinding, peci, tempat sandal, kotak tisu ,danlainnya.

2. Membentuk bank sampah disetiap rumah sebelum dikumpulkan pada bank sampah kelompok, sebagai sumber bahan baku produksi. 
3. Menjalin kerjasama dengan berbagai pihak seperti; Diskoperindakkop Lombok Barat, LSM yang bergerak dibidang Lingkungan hidup seperti Syawaludin, SE, dkk, Tutor Hj Nurnia, dan lainnya.

4. Perlu memikirkan untuk melakukan kegiatan ini kearah bisnis, sehingga katakata upaya menambah pendapatan masyarakat dapat diwujudkan.

5. Perlu bentuk kelompok sebagai sarana bersama dalam mengembangkan aktivitas bisnis dalam bidang hasil pemanfaatan sampah non-organik kedepan.

6. Perlu adanya showroom di kantor desa ataupun tempat lainnya sebagai wahana promosi dan pemasaran.

\section{UCAPAN TERIMA KASIH}

Pelaksanaan kegiatan Pengabdian Kepada Masyarakat ini telah melibatkan berbagai pihak, oleh karena itu pada kesempatan ini kami mengucapkan terima kasih dan penghargaan kepada :

1 Ketua LPPM Unram yang telahmenyediakan dana pengabdian DIPA BLU Unram Th 2019.

2 Kepala Desa Kuranji Dalang beserta staff yang telah mendukung kegiatan pengabdian dengan menyiapkan ruangan dan fasilitas pendukung lain yang diperlukan.

3 Kelompok Wanita Tani Nelayan dan Kelompok Bank Sampah Desa Kuranji Dalang yang telah bersedia untuk memotivasi dan mengikuti kegiatan pelatihan. 


\section{Jurnal ABDIMAS INDEPENDEN}

Vol. 1, No. 2, November 2020

\section{DAFTAR PUSTAKA}

Undang-Undang No.23 Tahun 1997 tentang Pengelolaan Lingkungan Hidup

. Undang-undang No. 18 Tahun 2008 tentang Pengelolaan Sampah.

Nitikesari, Putu Ening. 2005. Analisis Tingkat Partisipasi Masyarakat dalam Penanganan Sampah Secara Mandiri di Kota Denpasar.Tesis Magister Program Pascasarjana Universitas Udayana, Denpasar.

Novi Marliani.2013.Pemanfaatan Limbah Rumah Tangga (Sampah Anorganik) sebagai Bentuk Implementasi Pendidikan Lingkungan Hidup, Program Studi Pendidikan Matematika Fakultas Teknik, Matematika Ilmu Pengetahuan Alam - Universitas Indra prasta. 